\title{
The Preparation and Characterization of Tourmaline-Containing Functional Copolymer p (VST/MMA/BA)
}

\author{
Yingmo Hu (D), Yunhua Li, Mengcan Li, Guocheng Lv ${ }^{D}$, Quan Liu, and Chunyan Hou \\ Beijing Key Laboratory of Materials Utilization of Nonmetallic Minerals and Solid Wastes, National Laboratory of Mineral \\ Materials, School of Materials Science and Technology, China University of Geosciences, Beijing 100083, China \\ Correspondence should be addressed to Yingmo Hu; huyingmo@cugb.edu.cn and Guocheng Lv; guochenglv@cugb.edu.cn
}

Received 14 December 2017; Accepted 3 April 2018; Published 7 May 2018

Academic Editor: Maria Carmen Yebra-Biurrun

Copyright (c) 2018 Yingmo Hu et al. This is an open access article distributed under the Creative Commons Attribution License, which permits unrestricted use, distribution, and reproduction in any medium, provided the original work is properly cited.

\begin{abstract}
Tourmaline was modified with vinyl triethoxysilane containing double bond to prepare the polymerizable organic vinylsiliconoxyl tourmaline (VST) and then copolymerized with methyl methacrylate (MMA) and butyl acrylate (BA) to produce the tourmalinecontaining functional copolymer $\mathrm{p}$ (VST/MMA/BA). The structures and morphologies of VST and $\mathrm{p}$ (VST/MMA/BA) copolymer were characterized by IR, SEM, and EDX. The experimental results indicated that tourmaline was introduced into the copolymer via surface modification and the tourmaline-containing functional copolymer was obtained by a copolymerization process with MMA and BA. The prepared p (VST/MMA/BA) copolymer displayed excellent storage stabilities, high far-infrared radiation and negative ion releasing performances, and good mechanical properties.
\end{abstract}

\section{Introduction}

Negative oxygen ions possess the efficacy of promoting metabolism of the human body, being able to prevent influenza, enhance human immune system, and restore the balance of the human body [1]. As such, materials able to release negative oxygen ions have attracted great attention recently and are applied in many fields, for example, as additives of building materials, textile fibers, health products, and cosmetics [2].

Tourmaline, with the chemical formula of $\mathrm{NaR}_{3} \mathrm{Al}_{6}(-$ $\left.\mathrm{Si}_{6} \mathrm{O}_{18}\right)\left(\mathrm{BO}_{3}\right)_{3}(\mathrm{OH}, \mathrm{F})_{4}(\mathrm{R}$ is $\mathrm{Mg}, \mathrm{Fe}, \mathrm{Li}$, or $\mathrm{Mn})$ [3-5], is a natural cyclosilicate mineral. Because of its special chemical structure, it possesses many unique physical and chemical properties [6], such as far-infrared radiation $[7,8]$ and negative ion release $[9,10]$. As such, a variety of applications of tourmaline have been developed [11-16]. If tourmaline could be added into polymers to prepare functional polymers, its applications could be further expanded to functional health-care products and functional materials $[17,18]$.

However, tourmaline powders could not be dispersed well in nonpolar polymers due to the high polarity of its surface. Surface modification by organic materials was commonly used to render its surface polarity and to prepare tourmaline/polymer composites [19, 20]. A tourmaline- containing functional copolymer, if it could be produced, would provide a new channel to fabricate novel functional materials and devices. Previously, we prepared the tourmaline-containing functional copolymer $\mathrm{p}$ (TUC/BA/ MMA), which displayed an excellent storage stability, excellent mechanical properties, superior performance in farinfrared radiation, and enhanced negative ion release [21].

In the present study, we developed a new method to prepare tourmaline-containing functional copolymer. Tourmaline was modified first with a silane coupling agent containing double bond to synthesize polymerizable organic vinylsiliconoxyl tourmaline (VST). Then, tourmalinecontaining functional copolymer $\mathrm{p}$ (VST/MMA/BA) was fabricated by copolymerizing VST with methyl methacrylate (MMA) and butyl acrylate (BA). The structures and morphologies of VST and copolymer $\mathrm{p}$ (VST/MMA/BA) were characterized by IR, SEM, and EDX, and their mechanical properties and performances in far-infrared radiation and negative ion release were evaluated quantitatively.

\section{Experimental}

2.1. Materials and Characterization. The tourmaline $(8000$ mesh) was obtained from Yanxin Mineral Co. Ltd., Hebei, 
China. Ethanol was purchased from Beijing Chemical Works. Benzoyl peroxide (BPO), butyl acrylate (BA), N,Ndimethylformamide (DMF), vinyltriethoxysilane, and methyl methacrylate (MMA) were purchased from Sinopharm Chemical Reagent Co. Ltd.

A PerkinElmer Spectrum 100 Fourier transform infrared spectrometer was used to obtain the FT-IR spectra of the samples over the $4000-400 \mathrm{~cm}^{-1}$ range. A scanning electron microscopy (SEM, S-450 made by Hitachi) was operated at $20 \mathrm{kV}$ for the microstructure images. And the elements of samples were analyzed by an energy dispersive X-ray spectroscopy (EDX) attached to the SEM. The mechanical properties and viscosity of the copolymers were tested by the CMT4304 electronic universal testing machine controlled by a microcomputer and SNB-3 digital viscometer, respectively. A 5DX Fourier transform infrared spectrometer was utilized to measure the far-infrared radiation of copolymers. And an air ion counter (Alpha Lab Inc., USA) was used to quantify the negative ions released from the copolymers at room temperature.

2.2. Preparation of Polymerizable Vinylsiliconoxyl Tourmaline (VST). Tourmaline (5g) and vinyl triethoxysilane $(1 \mathrm{~g})$ were added into a three-neck flask and reacted for $1.5 \mathrm{~h}$ at $60^{\circ} \mathrm{C}$ in $50 \mathrm{~mL}$ of mixture of ethanol and distilled water with a volume ratio of $1: 5$ under $\mathrm{pH} 9$. And the product was filtrated and washed three times with ethanol, then dried naturally.

2.3. Develop of Copolymer p (VST/MMA/BA). $20 \mathrm{~mL}$ DMF was poured into a four-neck flask connected to a reflux condensing tube, a constant pressure funnel, and a leading tube of nitrogen. The nitrogen was fluxed for $30 \mathrm{~min}$ to displace the gas in the flask. Then $20 \mathrm{~mL}$ of mixture of BA and MMA $(1: 1)$ dissolved in BPO was added to the flask with stir via the constant pressure funnel under $70^{\circ} \mathrm{C} .2 \mathrm{~g}$ polymerizable organic VST was added into the flask while the viscosity started to rise and the reaction lasted for $9 \mathrm{~h}$ at $70^{\circ} \mathrm{C}$ under stirring to obtain the tourmaline-containing functional copolymer p (VST/MMA/BA).

\section{Results and Discussion}

\subsection{Characterization of Polymerizable Organic VST}

3.1.1. IR Spectra. The typical absorption bands of $\mathrm{OH}, \mathrm{B}-\mathrm{O}$, and $\mathrm{Si}-\mathrm{O}$ groups of raw tourmaline (Figure 1(a)) were located at 3563,1280 , and $977 \mathrm{~cm}^{-1}$, respectively [22]. In contrast, the spectrum of modified tourmaline (Figure 1(b)) displayed new absorption bands at $3069 \mathrm{~cm}^{-1}$ (vinyl), $2957 \mathrm{~cm}^{-1}$ (methyl), and $1661 \mathrm{~cm}^{-1}$ (double bond). The typical absorption bands of tourmaline showed a few wavenumbers of redshift due to the electronic effect of the tourmaline powder's surface linked with the vinylsiliconoxyl [23]. The FTIR results confirmed that vinylsiliconoxyl was introduced onto the surface of tourmaline to produce the polymerizable organic VST via surface modification (Scheme 1).

3.1.2. SEM Images. The SEM images showed different surface properties between the raw and modified tourmaline. The

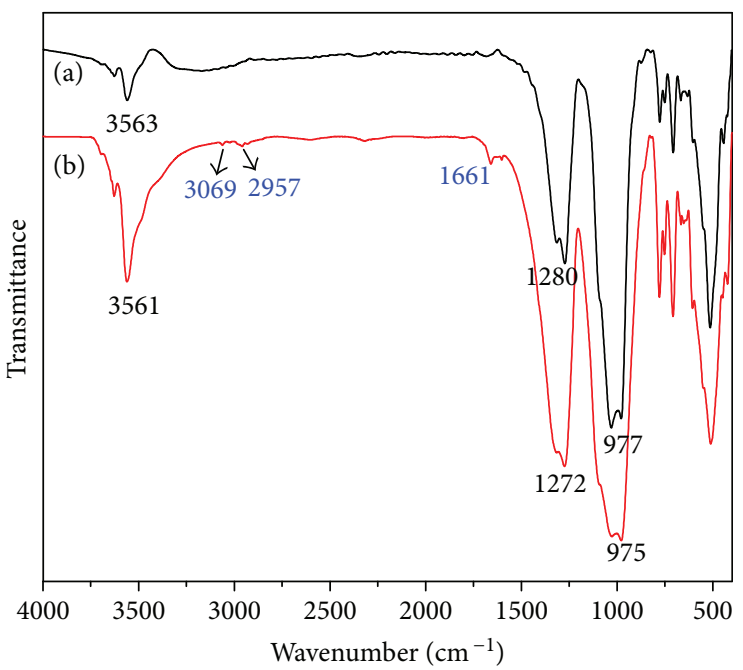

FIGURE 1: IR spectra of unmodified tourmaline (a) and modified tourmaline (b).

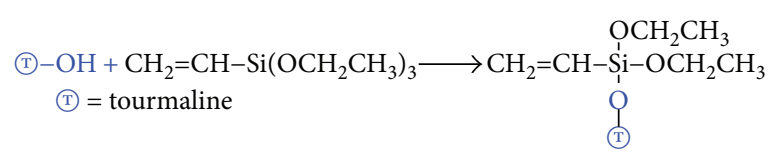

Scheme 1: Surface modification of tourmaline to form VST.

modified tourmaline appeared to have excellent dispersivity (Figure 2(b)) in contrast to the heavy agglomeration of unmodified one (Figure 2(a)). The organic vinylsiliconoxyl group on tourmaline surfaces after modification would reduce the surface polarity and significantly increased the hydrophobicity and dispersivity of tourmaline powders [24].

3.1.3. Far-Infrared Radiation Analysis. The far-infrared emissivity of unmodified and modified tourmaline was measured over the 8-24 $\mu \mathrm{m}$ wavelength range (Figure 3 ). A higher farinfrared emissivity (about 0.95 ) was found for the modified tourmaline, in comparison to about 0.87 for the unmodified one. This could be attributed to the reduced surface polarity, improved dispersivity, and increased surface areas of tourmaline powders after surface modification [25].

3.1.4. Negative Ion Release. The amounts of negative ions released by raw and modified tourmaline were all far more than those by air (Table 1), and modified tourmaline exhibited higher amount of negative ion release than that of unmodified tourmaline.

\subsection{Characterization of $p$ (VST/MMA/BA)}

3.2.1. IR Spectra of Copolymer p (VST/MMA/BA). The IR spectrum of the copolymer showed the absorption peaks of methyl at $2970 \mathrm{~cm}^{-1}$ and $2850 \mathrm{~cm}^{-1}$, carbonyl group at $1737 \mathrm{~cm}^{-1}$, C-H bending vibrations at $1447 \mathrm{~cm}^{-1}$ and $1381 \mathrm{~cm}^{-1}$, and $\mathrm{C}-\mathrm{O}$ band at $1162 \mathrm{~cm}^{-1}$ (Figure 4), in addition to the typical absorption bands of tourmaline at $3446 \mathrm{~cm}^{-1}$ (OH group), $1242 \mathrm{~cm}^{-1}$ (B-O band), and $988 \mathrm{~cm}^{-1}$ band (Si-O) [22]. However, the double-bond 


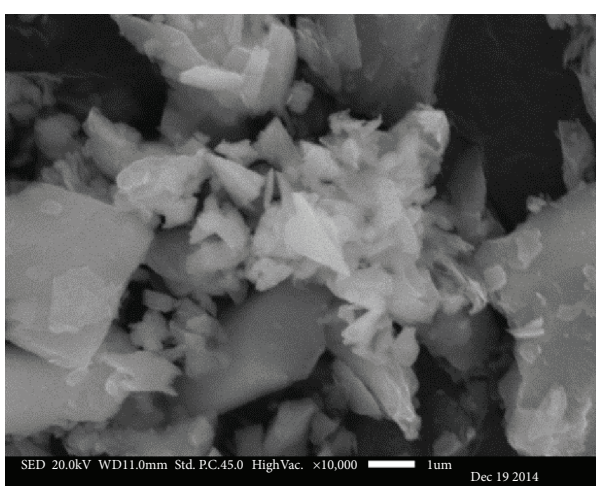

(a)

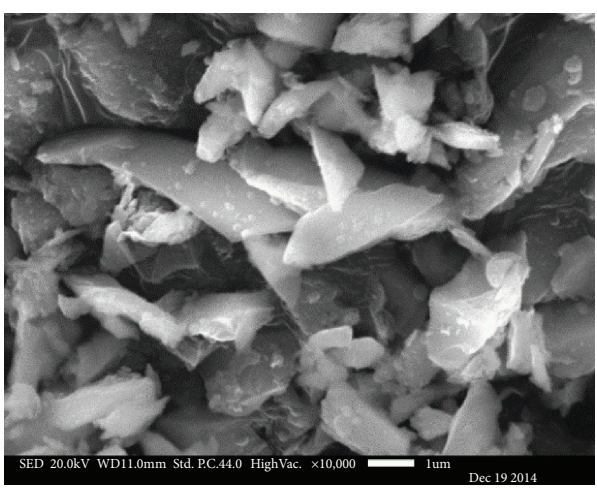

(b)

Figure 2: SEM images of unmodified tourmaline (a) and modified tourmaline (b).

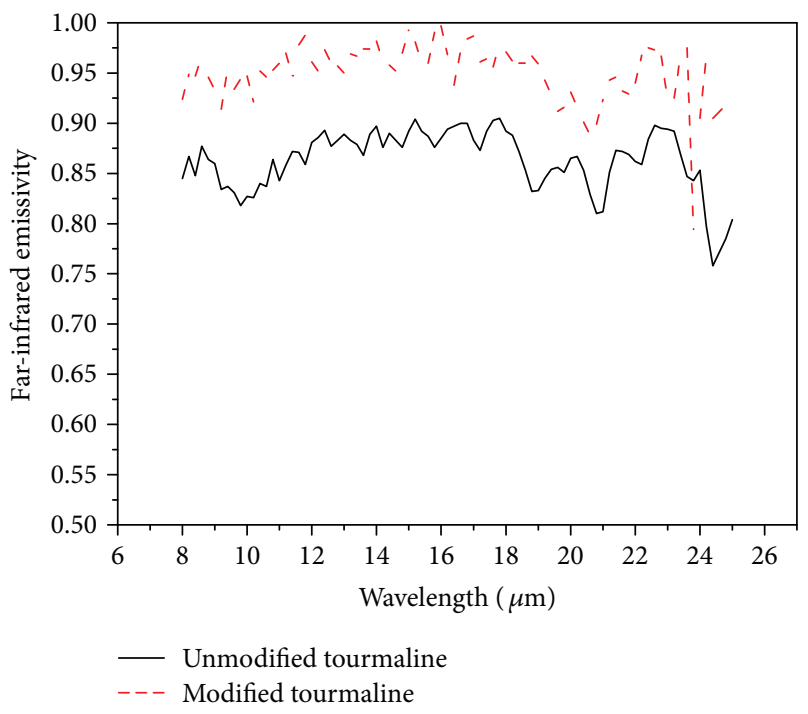

FIGURE 3: Far-infrared emissivity of unmodified and modified tourmaline.

TABLE 1: The amount of negative ions released by air, tourmaline, and modified tourmaline.

\begin{tabular}{lc}
\hline Samples & The amount of negative ions (ions $/ \mathrm{cm}^{3}$ ) \\
\hline Air & 192 \\
Unmodified tourmaline & 433 \\
Modified tourmaline & 575 \\
\hline
\end{tabular}

absorption disappeared in this spectrum. These results manifested that the copolymerization took place among BA, MMA, and organic VST to form the tourmaline-containing copolymer $\mathrm{p}$ (VST/MMA/BA).

3.2.2. The Viscosity of Copolymer $p$ (VST/MMA/BA). The viscosity of copolymer p (VST/MMA/BA) was high and increased with the increase of VST dosage at the initial stage (Table 2) and peaked at $1 \%$ of VST dosage. This may indicate that VST could copolymerize with BA and MMA effectively, and the heteroatoms of tourmaline might lead to the

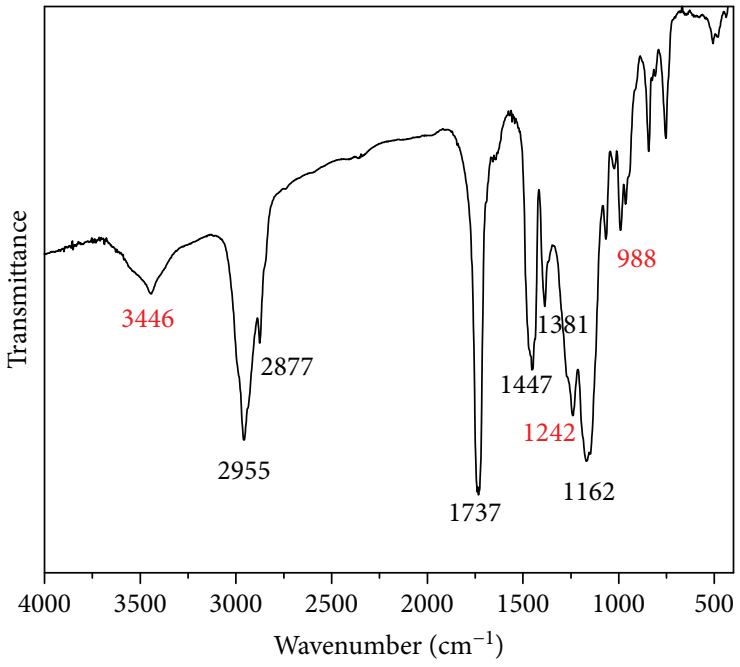

FIGURE 4: The IR spectrum of $\mathrm{p}$ (VST/MMA/BA) copolymer.

TABLE 2: Viscosity of $\mathrm{p}$ (VST/MMA/BA) copolymer with different dosages of VST.

\begin{tabular}{lc}
\hline Dosage of VST $(\%)$ & Viscosity of copolymer $(\mathrm{mPa} \cdot \mathrm{s})$ \\
\hline 0.3 & 280,650 \\
0.8 & 294,507 \\
1 & 309,953 \\
2 & 252,831 \\
3 & 239,149 \\
\hline
\end{tabular}

interaction of copolymer chain. But an excess of tourmaline might separate the adjacent copolymer chain as a filler [26].

3.2.3. The Storage Stabilities of Copolymer $p$ (VST/MMA/BA). The storage stabilities of copolymer p (VST/MMA/BA) and copolymer of unmodified tourmaline with MMA and BA ( $\mathrm{p}$ (unmodified tourmaline/MMA/BA)) obtained under the same fabrication procedures were evaluated. All copolymers containing VST at a mass percentage of $0.3,1.0$, and 2.0 displayed excellent storage stabilities after 


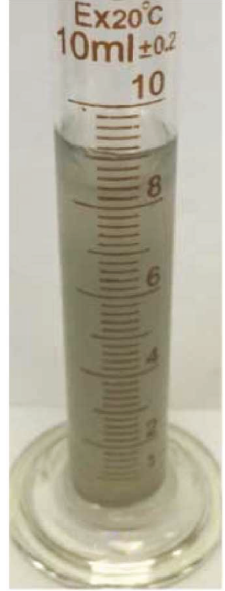

(a)

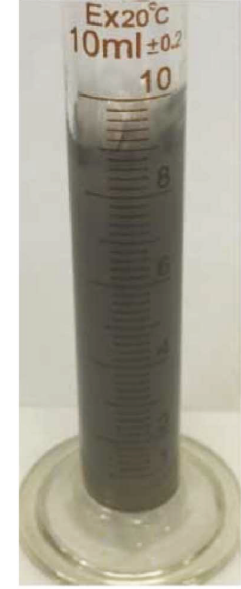

(b)

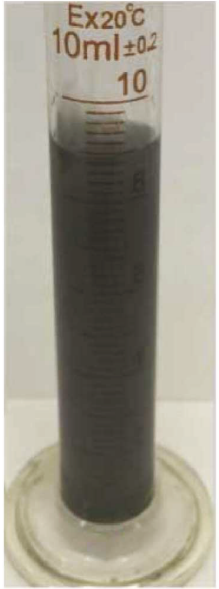

(c)

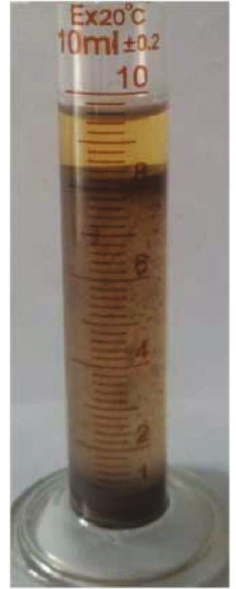

(d)

Figure 5: The storage stabilities of copolymer with VST $0.3 \%$ (a), $1 \%(b), 2 \%(c)$, and $2 \%$ unmodified tourmaline (d).

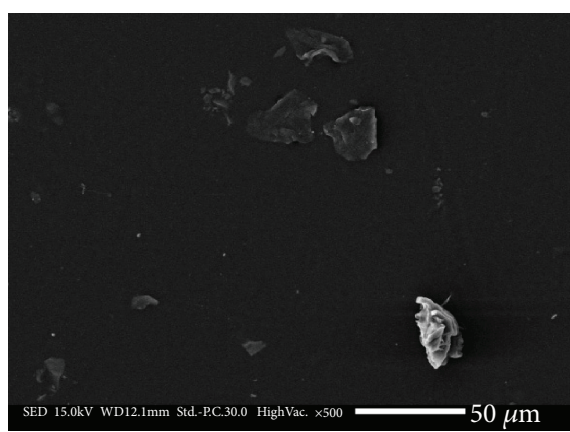

(a)

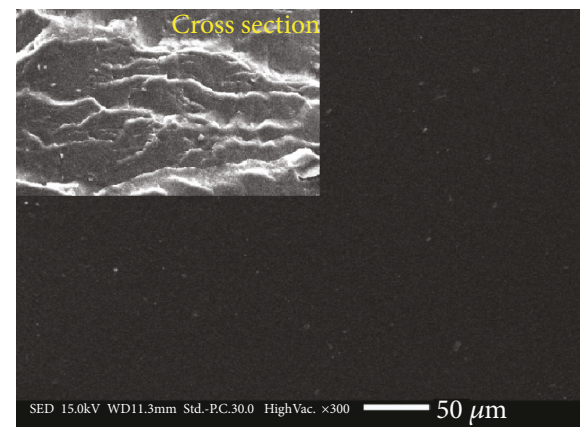

(b)

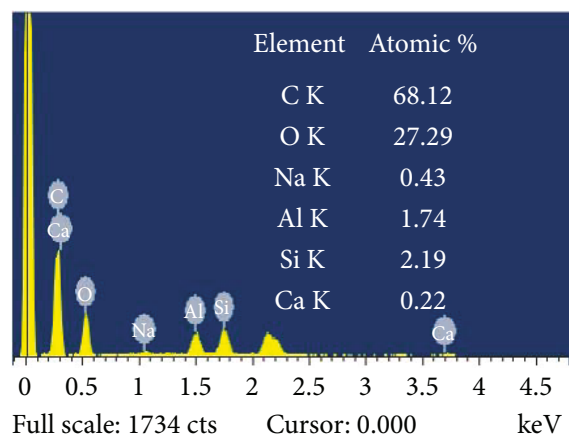

(c)

FIGURE 6: The surface SEM images of $\mathrm{p}$ (unmodified tourmaline/MMA/BA) (a) and p (VST/MMA/BA) (b) (inset was the cross section of the film) and the EDX analysis of p (VST/MMA/BA) copolymer (c).

30 days (Figures 5(a)-5(c)). In contrast, the $\mathrm{p}$ (unmodified tourmaline/MMA/BA) showed massive sedimentation (Figure 5(d)) observably while placed less than a week. The results suggested that VST was introduced into the copolymer via copolymerization with MMA and BA to obtain tourmaline-containing functional copolymer $p$ (VST/MMA/BA), while the unmodified tourmaline could not copolymerize with MMA and BA, but only form blended mixture with MMA and BA.
3.2.4. SEM Images and EDX Analysis. The SEM image of $\mathrm{p}$ (unmodified tourmaline/MMA/BA) (Figure 6(a)) showed obvious reunion of tourmaline for its strong polarity, while the $\mathrm{p}$ (VST/MMA/BA) exhibited well distribution of tourmaline on both the surface and the interior of copolymer film (Figure 6(b)). The rough and uneven surface of the cross section shown in the inset image (Figure 6(b)) revealed that the $\mathrm{p}$ (VST/MMA/BA) film had good mechanical properties and is not brittle. 


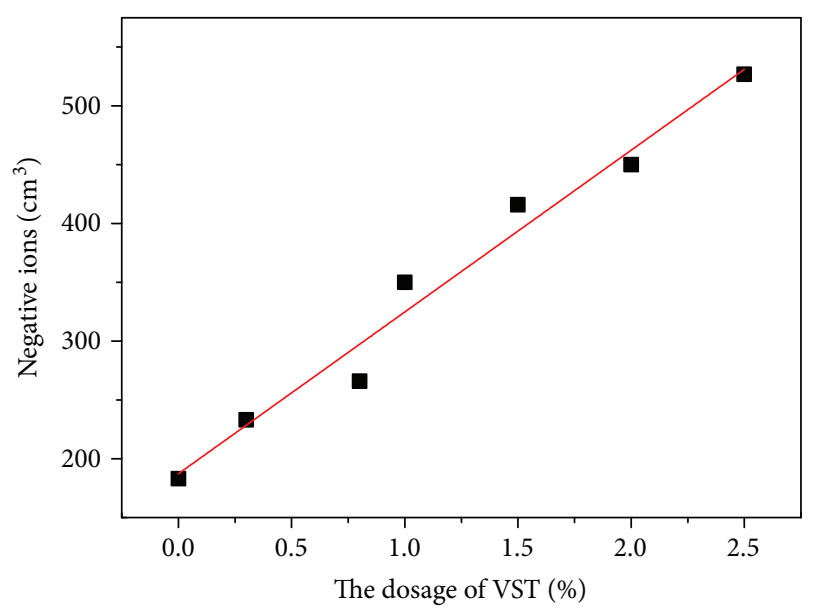

FIGURE 7: The amount of negative ions released from $\mathrm{p}$ (VST/ MMA/BA) copolymer.

Furthermore, the EDX elemental analysis of $\mathrm{p}$ (VST/ MMA/BA) copolymer (Figure 6(c)) further confirmed the presence of tourmaline in the copolymer by surface modification and copolymerization to form $\mathrm{p}$ (VST/MMA/BA).

3.3. The Performance Characterization of $p$ (VST/MMA/BA) Copolymer. In order to study the performance of $\mathrm{p}$ (VST/ MMA/BA) copolymer, the influence of VST dosage on the properties of negative ion release, far-infrared radiation, and mechanical properties of $\mathrm{p}$ (VST/MMA/BA) copolymer film were investigated quantitatively.

3.3.1. The Negative Air Ion Releasing Property. The amount of negative ions released from $\mathrm{p}$ (VST/MMA/BA) copolymer increased linearly with the increase of VST dosage (Figure 7). These results were in accordance with the good dispersivity of modified tourmaline. With a bamboo charcoal content of $12 \%$, poly(ethylene terephthalate)/polypropylene/ bamboo charcoal (PET/PP/BC) thermoplastic composites could only produce negative air ions of $110-200$ per $\mathrm{cm}^{3}$ [27]. The average negative air ion releasing was about 150 per $\mathrm{cm}^{3}$ for ethylene propylene diene terpolymer/polypropylene and tourmaline composite films [28]. The negative air ion releasing reached maximum of 300 per $\mathrm{cm}^{3}$ [29] at the tourmaline content of $5 \%$ in tourmaline-containing polypropylene composition films. The product developed from this study reached to 500 per $\mathrm{cm}^{3}$ at a VST loading level of only $2.5 \%$ (Figure 7 ), much better than previous developed materials.

3.3.2. Far-Infrared Radiation Emissivity. The far-infrared radiation emissivity of $\mathrm{p}$ (VST/MMA/BA) copolymer, tested from 8 to $24 \mu \mathrm{m}$ wavelength at room temperature using the 5DX Fourier transform infrared spectrometer, was listed in Table 3. For $\mathrm{p}$ (VST/MMA/BA) copolymer, the far-infrared emissivity values were all high (about 0.96 ) and remained more or less the same regardless of the amount of VST in the copolymer. The results are much better than 0.85 for poly(ethylene terephthalate)/polypropylene/bamboo charcoal (PET/PP/BC) thermoplastic composites [27] and better
TABLE 3: Far-infrared emissivity of $\mathrm{p}$ (VST/MMA/BA) copolymer with different contents of VST.

\begin{tabular}{lc}
\hline The dosage of VST (\%) & Far-infrared emissivity rate \\
\hline 0.3 & 0.958 \\
0.8 & 0.959 \\
1.5 & 0.950 \\
2.0 & 0.956 \\
2.5 & 0.962 \\
\hline
\end{tabular}

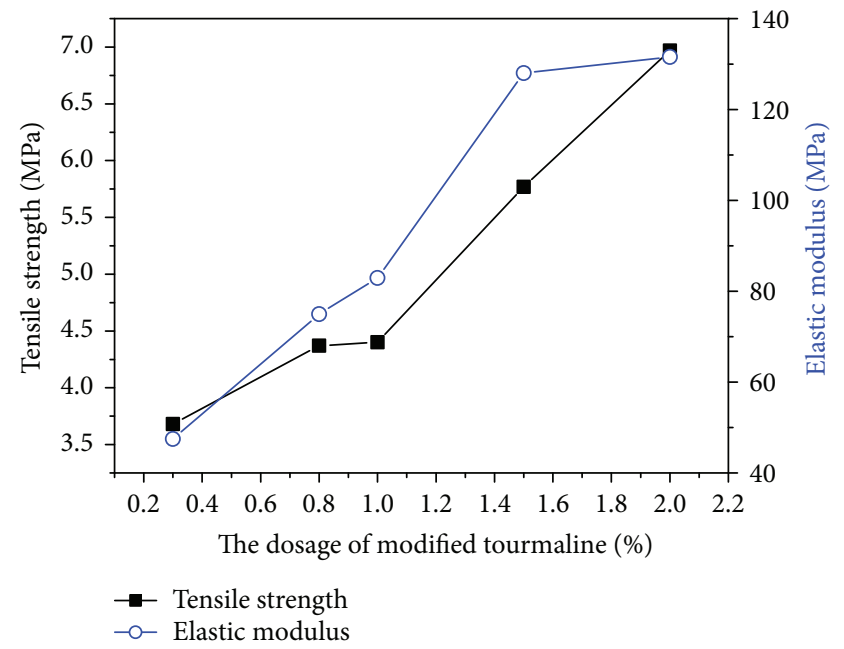

Figure 8: The mechanical properties of $\mathrm{p}$ (VST/MMA/BA) copolymers.

than 0.9 for paperboards coated with $40 \mathrm{~g} / \mathrm{m}^{2}$ far-infrared emission functional materials [30]. In contrast, the farinfrared emissivity of tourmaline/graphene oxide (at tourmaline/graphene oxide ratio of $85: 15)$ showed merely an enhancement of $4 \%$ in far-infrared emission than that of tourmaline alone [31]. The near constant results suggested that modified tourmaline distributed uniformly in the copolymer and the distribution of tourmaline on the surface of the film did not increase evidently [32].

3.3.3. Mechanical Properties. The mechanical properties of $\mathrm{p}$ (VST/MMA/BA) copolymer with different added amounts of VST were tested according to the standard GB 13022-1991 [33]. Both the elastic modulus and tensile strength of $p$ (VST/MMA/BA) copolymers increased with increasing VST dosage (Figure 8). The results suggested that tourmaline was introduced into $\mathrm{p}$ (VST/MMA/BA) copolymer with chemical bonding via the surface modification and copolymerization with MMA and BA, which enhanced the acting force effectively among polymer chains [21].

\section{Conclusions}

The polymerizable organic vinylsiliconoxyl tourmaline (VST) was prepared by surface modification of tourmaline with vinyl triethoxysilane and then copolymerized with MMA and BA to fabricate tourmaline-containing functional 
copolymer $\mathrm{p}$ (VST/MMA/BA). The structures and morphologies of VST and p (VST/MMA/BA) copolymer were characterized by IR, SEM, and EDX.

The experimental results revealed that the organic modified tourmaline presented better negative ion releasing and far-infrared radiating properties due to a reduction of surface polarity, improvement of dispersivity, and increase of surface areas after organic modification. And the $\mathrm{p}$ (VST/MMA/BA) copolymer displayed excellent storage stabilities, high farinfrared radiation, and better negative ion releasing performances with good mechanical properties. The results suggested that tourmaline was introduced into the copolymer via surface modification and copolymerization with MMA and BA to achieve tourmaline-containing functional copolymer. This work presented a new way to develop mineralcontaining functional copolymers and functional materials.

\section{Conflicts of Interest}

The authors declare that there is no conflict of interests regarding the publication of this paper.

\section{Acknowledgments}

This work is supported by the National Natural Science Foundation of China (no. 51372233).

\section{References}

[1] A. Kumar, A. G. C. Nair, A. V. R. Reddy, and A. N. Garg, "Availability of essential elements in bhasmas: analysis of ayurvedic metallic preparations by INAA," Journal of Radioanalytical and Nuclear Chemistry, vol. 270, no. 1, pp. 173-180, 2006.

[2] G. P. Smith, L. C. Lee, and J. T. Moseley, "Photodissociation and photodetachment of molecular negative ions. VII. Ions formed in $\mathrm{CO}_{2} / \mathrm{O}_{2} / \mathrm{H}_{2} \mathrm{O}$ mixtures, 3500-5300 $\AA$," The Journal of Chemical Physics, vol. 71, no. 10, pp. 4034-4041, 1979.

[3] L. Yu, C. Wang, X. Ren, and H. Sun, "Catalytic oxidative degradation of bisphenol A using an ultrasonic-assisted tourmaline-based system: influence factors and mechanism study," Chemical Engineering Journal, vol. 252, no. 18, pp. 346-354, 2014.

[4] D. L. Guerra, S. P. Oliveira, R. A. R. Silva, V. Leidens, and A. C. Batista, "Characterization and application of tourmaline and beryl from Brazilian pegmatite in adsorption process with divalent metals," International Journal of Mining Science and Technology, vol. 22, no. 5, pp. 711-718, 2012.

[5] D. L. Guerra, S. P. Oliveira, E. M. Silva, and A. C. Batista, "Adsorption of uranyl on beryl and tourmaline; kinetics and thermodynamic investigation," International Journal of Mineral Processing, vol. 102-103, pp. 25-31, 2012.

[6] L. D. Tijing, M. T. G. Ruelo, A. Amarjargal et al., "Antibacterial and superhydrophilic electrospun polyurethane nanocomposite fibers containing tourmaline nanoparticles," Chemical Engineering Journal, vol. 197, no. 14, pp. 41-48, 2012.

[7] G. Xue, X. M. Wu, J. S. Liang, Y. Ding, and L. H. Liu, "Effect of Mineral Composite Materials with Far Infrared Radiation on Diesel Oil Combustion," Advanced Materials Research, vol. 58, pp. 47-53, 2008.
[8] J. Liu, J. Meng, J. Liang, X. Duan, X. Huo, and Q. Tang, "Effect of rare earth Ce on the far infrared radiation property of iron ore tailings ceramics," Materials Research Bulletin, vol. 66, pp. 26-31, 2015.

[9] J.-T. Yeh, W. Wei, H.-H. Hsiung, and T. Jiang, "An investigation of negative air ions releasing properties of tourmaline contained polypropylene resins," Journal of Polymer Engineering, vol. 26, no. 1, pp. 17-132, 2006.

[10] C. Wang, J. Liu, Z. Zhang, B. L. Wang, and H. Sun, "Adsorption of $\mathrm{Cd}(\mathrm{II}), \mathrm{Ni}(\mathrm{II})$, and $\mathrm{Zn}(\mathrm{II})$ by tourmaline at acidic conditions: kinetics, thermodynamics, and mechanisms," Industrial \& Engineering Chemistry Research, vol. 51, no. 11, pp. 4397-4406, 2012.

[11] M. S. Xia, C. H. Hu, and H. M. Zhang, "Effects of tourmaline addition on the dehydrogenase activity of Rhodopseudomonas palustris," Process Biochemistry, vol. 41, no. 1, pp. 221-225, 2006.

[12] H. Zhang, R. Zhang, G. Zhang, F. Yang, and F. Gao, "Modified graphite electrode by polyaniline/tourmaline improves the performance of bio-cathode microbial fuel cell," International Journal of Hydrogen Energy, vol. 39, no. 21, pp. 11250-11257, 2014.

[13] K. Jiang, T. Sun, L. Sun, and H. Li, "Adsorption characteristics of copper, lead, zinc and cadmium ions by tourmaline," Journal of Environmental Sciences, vol. 18, no. 6, pp. 1221-1225, 2006.

[14] B. Wang, C. Wang, J. Li, H. Sun, and Z. Xu, "Remediation of alkaline soil with heavy metal contamination using tourmaline as a novel amendment," Journal of Environmental Chemical Engineering, vol. 2, no. 3, pp. 1281-1286, 2014.

[15] J. S. Liang, J. P. Meng, G. C. Liang, Y. W. Feng, and Y. Ding, "Preparation and photocatalytic activity of composite films containing clustered $\mathrm{TiO}_{2}$ particles and mineral tourmaline powders," Transactions of Nonferrous Metals Society of China, vol. 16, Supplement 1, pp. s542-s546, 2006.

[16] T. Nakamura and T. Kubo, "Tourmaline group crystals reaction with water," Ferroelectrics, vol. 137, no. 1, pp. 13-31, 1992.

[17] S.-J. Kang, L. D. Tijing, B. Hwang, Z. Jiang, H. Y. Kim, and C. S. Kim, "Fabrication and photocatalytic activity of electrospun nylon- 6 nanofibers containing tourmaline and titanium dioxide nanoparticles," Ceramics International, vol. 39, no. 6, pp. 7143-7148, 2013.

[18] D. Ruan, L. Zhang, Z. Zhang, and X. Xia, "Structure and properties of regenerated cellulose/tourmaline nanocrystal composite films," Journal of Polymer Science Part B: Polymer Physics, vol. 42, no. 3, pp. 367-373, 2004.

[19] Y. Zheng and A. Wang, "Removal of heavy metals using polyvinyl alcohol semi-IPN poly (acrylic acid)/tourmaline composite optimized with response surface methodology," Chemical Engineering Journal, vol. 162, no. 1, pp. 186-193, 2010.

[20] R. R. Yeredla and H. Xu, "Incorporating Strong Polarity Minerals of Tourmaline with Semiconductor Titania to Improve the Photosplitting of Water," The Journal of Physical Chemistry C, vol. 112, no. 2, pp. 532-539, 2007.

[21] Y. Li, Y. Hu, Y. Liu, M. Li, Q. Liu, and C. Hou, "Preparation of tourmaline-containing functional copolymer $\mathrm{p}$ (TUC/BA/ MMA) and its performances," Soft Materials, vol. 14, no. 2, pp. 57-63, 2016.

[22] P. S. R. Prasad, "Study of structural disorder in natural tourmalines by infrared spectroscopy," Gondwana Research, vol. 8, no. 2, pp. 265-270, 2005. 
[23] S. Bandyopadhyay-Ghosh, S. B. Ghosh, and M. Sain, "Cellulose Nanocomposites," Industrial Applications of Natural Fibres: Structure, Properties and Technical Applications, 2010.

[24] Y. Hu and X. Yang, "The surface organic modification of tourmaline powder by span-60 and its composite," Applied Surface Science, vol. 258, no. 19, pp. 7540-7545, 2012.

[25] F. S. Lameiras, E. H. M. Nunes, and J. Maria Leal, "Backgrounds for the industrial use of black tourmaline based on its crystal structure characteristics," Ferroelectrics, vol. 377, no. 1, pp. 107-119, 2008.

[26] A. Jain, K. J. Prashanth, A. K. Sharma, A. Jain, and P. N. Rashmi, "Dielectric and piezoelectric properties of PVDF/ PZT composites: a review," Polymer Engineering \& Science, vol. 55, no. 7, pp. 1589-1616, 2015

[27] J. H. Lin, C. W. Lou, J. M. Chen, C. T. Hsieh, and Z. H. Liu, "PET/PP blend with bamboo charcoal to produce functional composites: evaluation of functionalities," Advanced Materials Research, vol. 55-57, pp. 433-436, 2008.

[28] J. T. Yeh, W. Wei, H. H. Hsiung, and T. Jiang, "Negative air ions releasing properties of tourmaline contained ethylene propylene diene terpolymer/polypropylene thermoplastic elastomers," Journal of Applied Polymer Science, vol. 109, no. 1, pp. 82-89, 2008.

[29] J.-T. Yeh, H.-H. Hsiung, W. Wei, P. Zhu, K.-N. Chen, and T. Jiang, "Negative air ion releasing properties of tourmaline/ bamboo charcoal compounds containing ethylene propylene diene terpolymer/polypropylene composites," Journal of Applied Polymer Science, vol. 113, no. 2, pp. 1097-1110, 2009.

[30] J. Y. Lee, C. H. Kim, H. G. Jung, T. G. Shin, and J. M. Seo, "Emission of far-infrared ray in packaging paper," Journal of Korea TAPPI, vol. 40, no. 5, pp. 47-52, 2008.

[31] Z. Huang, T. Wang, X. Zhang, L. Zheng, G. Xue, and J. Liang, "Preparation of tourmaline/graphene oxide and its application in thermal interface materials," Journal of Composite Materials, vol. 50, no. 28, pp. 3953-3960, 2016.

[32] L. J. Han, J. P. Meng, J. S. Liang, K. Gan, Y. Ding, and Y. D. Yuan, "Electric dipole characteristics of mineral tourmaline superfine powders and its properties of far infrared emission," Advanced Materials Research, vol. 178, pp. 129-132, 2011.

[33] Y. Yu, S. Qi, J. Zhan, Z. Wu, X. Yang, and D. Wu, "Polyimide/ sepiolite nanocomposite films: preparation, morphology and properties," Materials Research Bulletin, vol. 46, no. 10, pp. 1593-1599, 2011. 

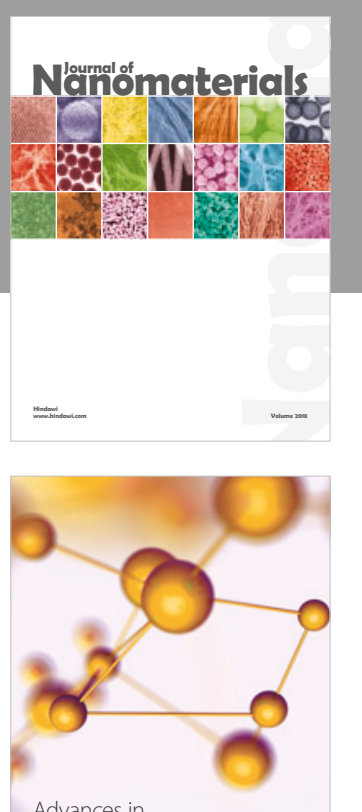

Physical Chemistry
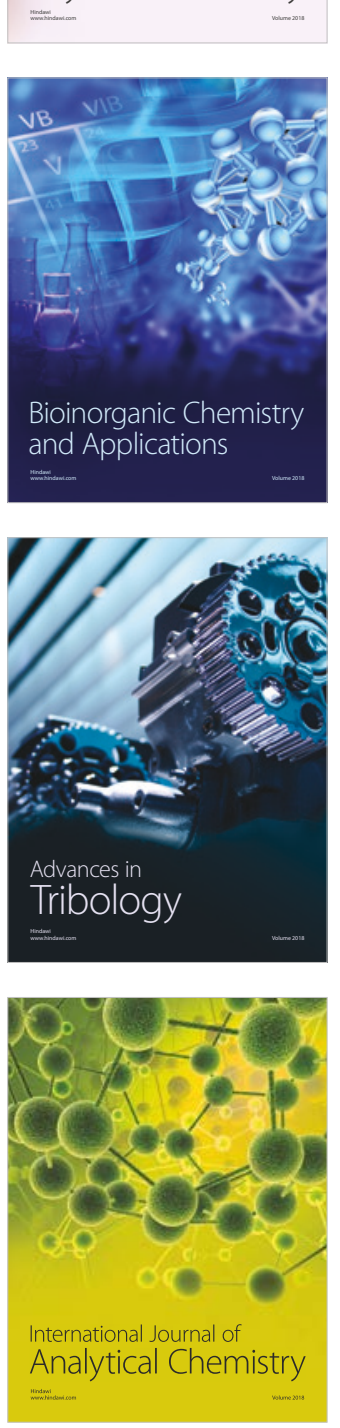

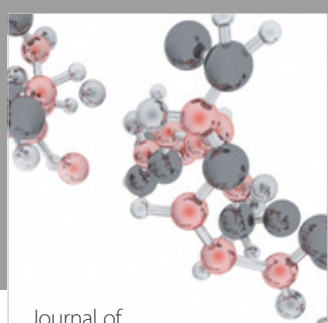

Analytical Methods

in Chemistry

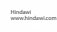

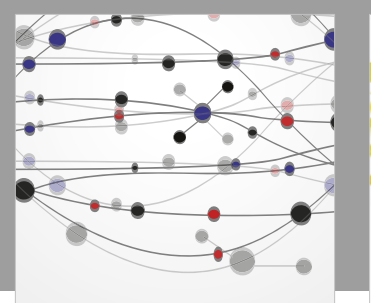

The Scientific World Journal

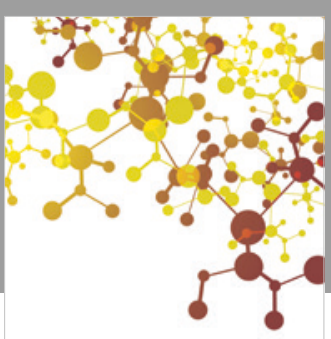

Journal of

Applied Chemistry
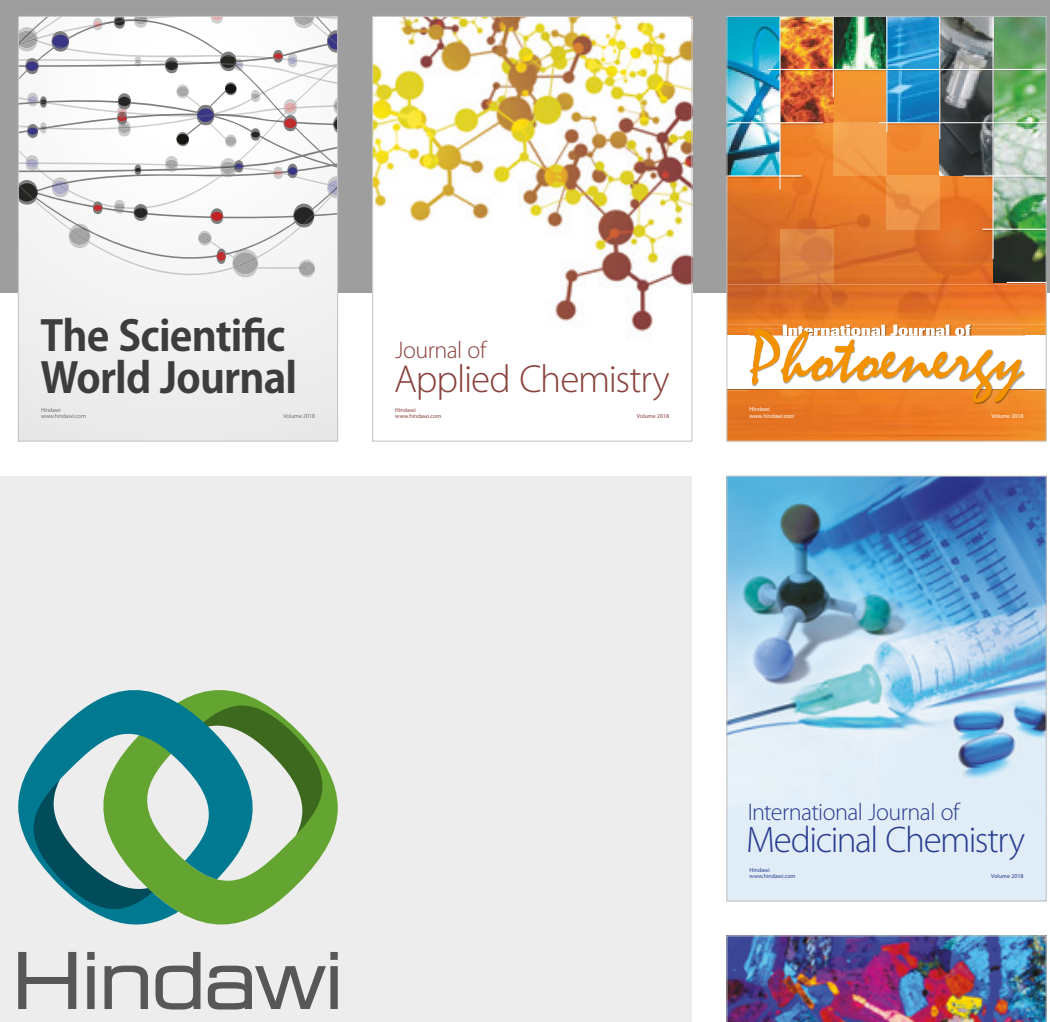

Submit your manuscripts at

www.hindawi.com
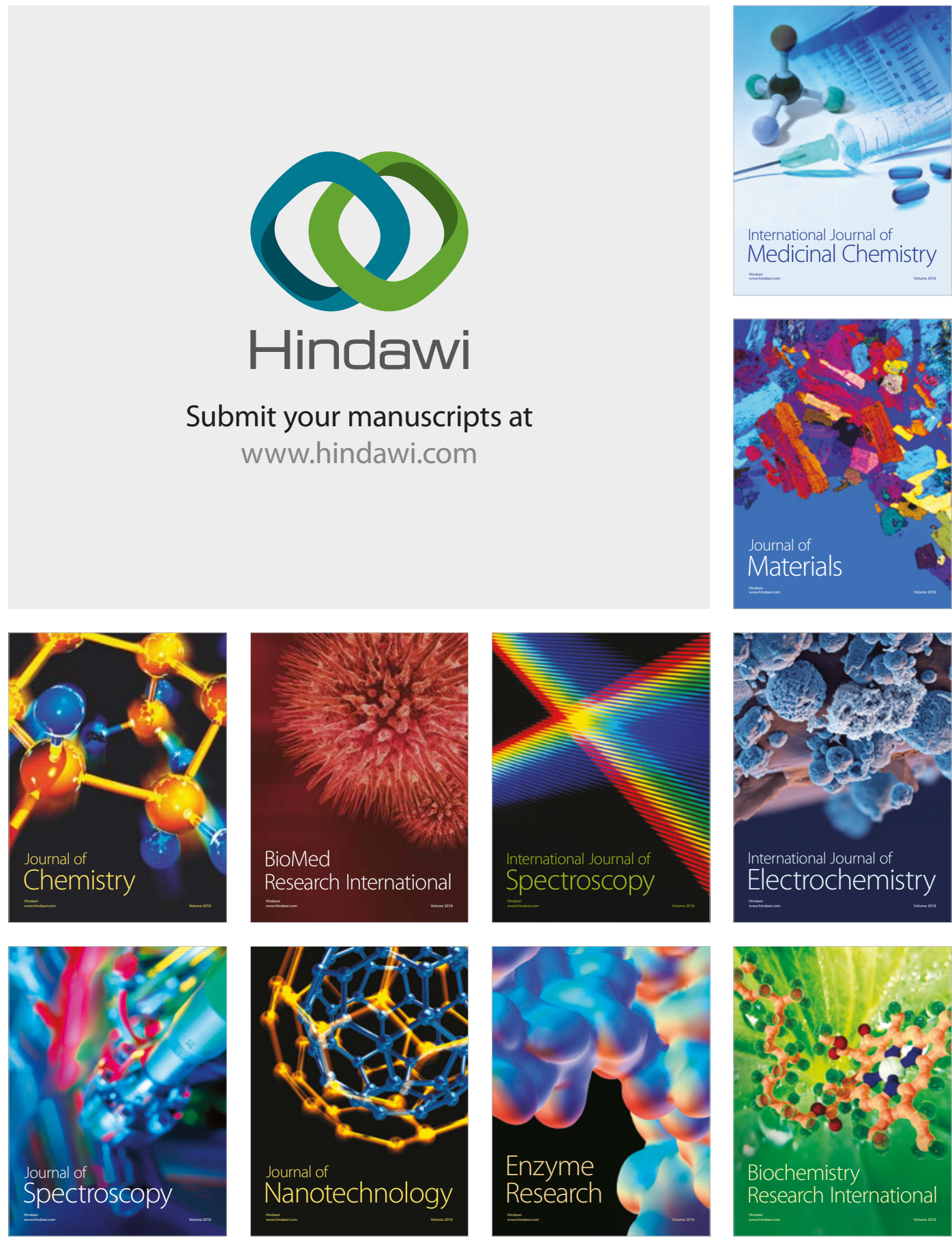
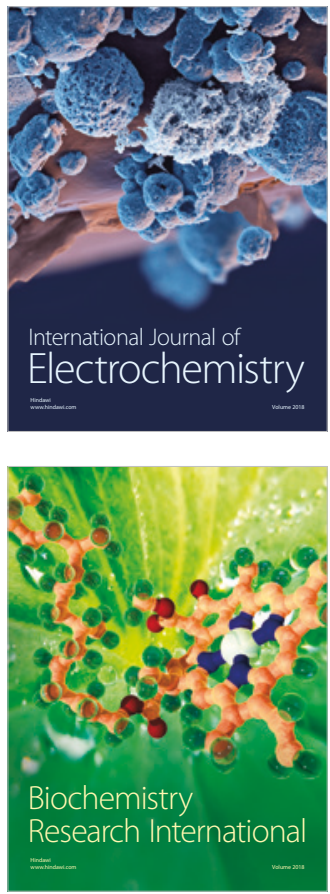